\title{
o-Aminomethylderivatives of phenols. Part 3. Mechanistic investigation of a Mannich reaction of phenols with N-methylenealkylamines
}

\author{
Krzysztof Bujnowski, Agnieszka Adamczyk-Woźniak, and Ludwik Synoradzki* \\ Faculty of Chemistry, Warsaw University of Technology, \\ Noakowskiego 3 Street, 00-664 Warsaw, Poland \\ E-mail: Ludwik.Synoradzki@,ch.pw.edu.pl
}

\begin{abstract}
The mechanism of the Mannich reaction of phenols (1) with 1,3,5-trialkyl-hexahydro-1,3,5triazines (2) as a source of $N$-methylenealkylamines (3) in organic solvent has been investigated. It has been determined that the formation of $o$-hydroxybenzylamine $\mathbf{4}$ and its subsequent quick transformation into benzoxazine $\mathbf{5}$ and primary amine in the reversible reaction with $\mathbf{3}$ takes place in the first stage of the process. Then, the yield of 4 slowly increases and that of 5 appropriately decreases as a result of the reaction of $\mathbf{3}$ with the so far unreacted $\mathbf{1}$ and the slow aminolysis of 5. In addition, benzyldiamine $\mathbf{6}$ is formed as a by-product (Scheme 1).
\end{abstract}

Keywords: Benzylamines, benzoxazines, Mannich reaction, 1,3,5-triazines, Nmethylenealkylamines

\section{Introduction}

$o$-Aminomethylderivatives of phenols exhibit many interesting chemical properties and are the subject of growing interest. Some of them were tested as potential metal complexing agents including metal ions extractants, catalysts or their components, semi-products in organic synthesis, biologically active agents or components of polymeric materials. ${ }^{1}$

In the search for a simple and efficient synthetic method of $\mathbf{4}$, the application of a well known Mannich reaction ${ }^{2}$ was spotted. The practical advantage of this "one-pot" process is the high availability of substrates - phenols, primary amines and formaldehyde. Its weak points are the possible side-reactions involving not only substrates but also products resulting in low yields of benzylamines synthesis. ${ }^{1}$ 


\section{Results and Discussion}

The subject of our research was a Mannich reaction, in which the traditionally used primary amine and formaldehyde were replaced by the product of their condensation - 1,3,5-trialkylhexahydro-1,3,5-triazine (2). (It is known that $\mathbf{2}$ splits at the reaction conditions with the formation of $\mathrm{N}$-methylenealkylamines (3), which are in fact the reactive species). ${ }^{3,4}$ In this case the process can be performed under anhydrous conditions, that enables precise analytical control at its every stage.

According to our review, not many attempts to study the considered variant of the Mannich reaction have been reported. ${ }^{1}$ The reaction of 1-naphthol with various $\mathbf{2}$ or/and $\mathbf{3}$ was investigated by Mörle and Tröster. ${ }^{5}$ The authors applied 1 mole of 2 per 3 mole of 1-naphthol and observed the formation of benzylamine that was transformed into hydrochloride by the action of gaseous $\mathrm{HCl}$. An analogous reaction of phenols with 2, carried out by Kostyuchenko et al. resulted in the formation of heterocyclic benzoxazine products. ${ }^{6}$ The mechanistic proposal of that transformation raises doubts as no additional proof was given. The application of sterically hindered monomeric products of primary amine and formaldehyde condensation in the synthesis of $o$-hydroxybenzylamines was patented by Exner and Craig in $1956 .{ }^{7}$ The described high yields of the synthesis, identification and purity of some of the synthesized products seem to be questionable.

The aim of our work was to explain the reaction mechanism of phenols (1) with $\mathrm{N}$ methylenealkylamines (3). $p$-Cresol (1a) was chosen as a model phenol substrate. The presence of the methyl group at para- position limits the number of possible products of aromatic substitution. In addition, a clear isolated singlet signal of the methyl group at $2.25 \mathrm{ppm}$ in the ${ }^{1} \mathrm{H}$ NMR spectrum is useful for quantitative analysis. A crystalline, stable and easy to purify 1,3,5tricyclohexyl-hexahydro-1,3,5-triazine (2a) was applied as a precursor of $\mathrm{N}$ methylenecyclohexylamine (3a). Due to the high boiling point of cyclohexylamine (bp $130^{\circ} \mathrm{C}$ ), it did not leave the refluxing reaction mixture and thus, it was possible to investigate its reactivity or influence on the yield of products. 1a and 2a were dissolved in methanol (the solvent usually used in standard Mannich reaction) at room temperature and then refluxed for $10 \mathrm{~h}$. It was found that in addition to benzylamine 4a, by-products benzoxazine 5a and benzyldiamine 6a (Scheme 1) were formed. In order to isolate $\mathbf{4 a}$, the post-reaction mixture was acidified with concentrated hydrochloric acid and the product separated in the form of a solid hydrochloride salt. Isolation of 5a and 6a from the multicomponent reaction mixture was difficult, so they were synthesized in supplementary reactions, isolated and fully characterized. 


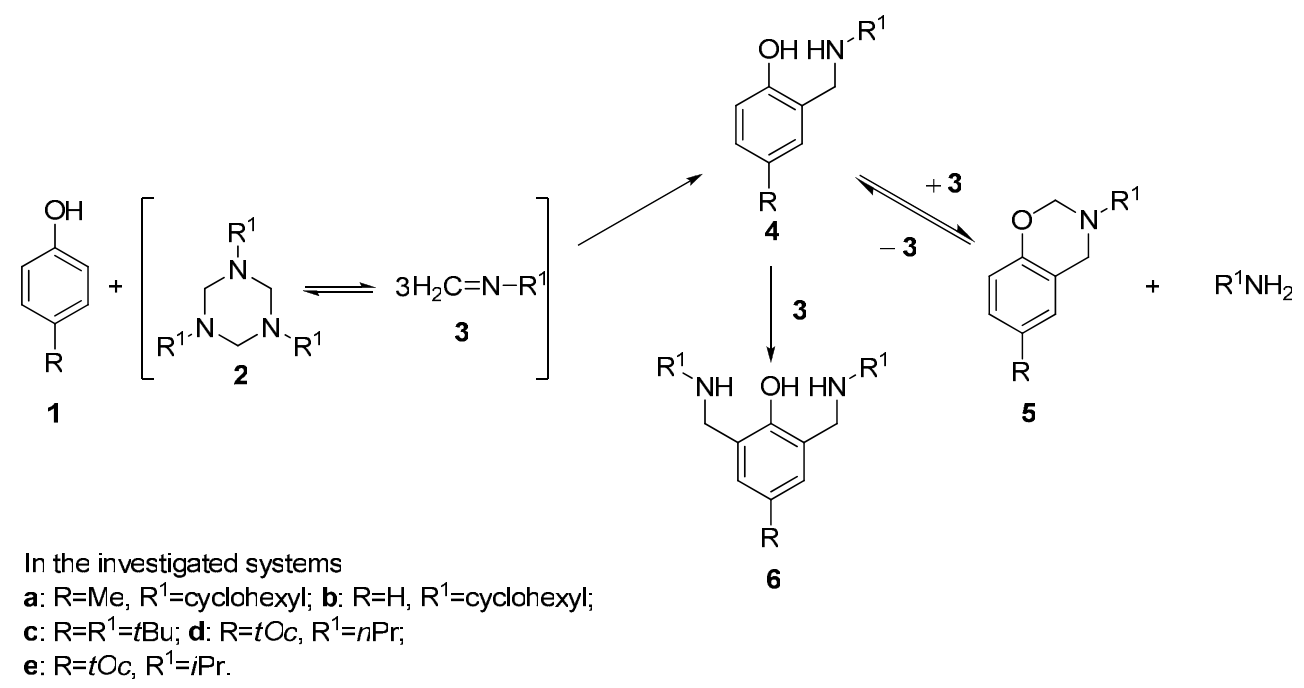

\section{Scheme 1}

To determine the reaction course and to correctly interpret the results, a convenient analytical method based on ${ }^{1} \mathrm{H}$ NMR spectroscopy has been elaborated. All the products originating from 1a contain a methyl group connected to the phenol ring. The integration of the appropriate group of signals (2.25-2.20 ppm) was used as an "internal standard", corresponding to the initial amount of 1a. The conversion of 1a at every stage of the process was determined basing on the integration of its isolated methyl signal at $2.25 \mathrm{ppm}$ versus the internal standard. The specific signals coming from methylene linkages at 3.86-4.95 ppm for 4a-6a, 3.54 ppm for $\mathbf{2 a}$ and at $7.21 \mathrm{ppm}$ for $\mathbf{3 a}$ allowed the determination of the yield or conversion of the appropriate products (Table 1). The cyclohexyl methylene groups' signals were observed in the range of 1.00-2.00 ppm and did not overlap with any of the considered ones. An example of the reaction mixture spectrum is presented (Figure 1).

Table 1. Analytical signals of the reaction mixture components in ${ }^{1} \mathrm{H}$ NMR spectra $\left(\mathrm{CDCl}_{3}\right)$

\begin{tabular}{|c|c|c|c|}
\hline Compound & Characteristic group & Number of protons & Chemical shift (ppm) \\
\hline $1 \mathrm{a}$ & $\mathrm{C}-\mathrm{CH}_{3}$ & $3 \mathrm{H}$ & 2.25 \\
\hline $2 \mathbf{a}$ & $\mathrm{N}-\mathrm{CH}_{2}-\mathrm{N}$ & $6 \mathrm{H}$ & 3.54 \\
\hline $3 \mathbf{a}$ & $\mathrm{N}=\mathrm{CH}_{2}$ & $2 \mathrm{H}$ & 7.21 \\
\hline $4 a$ & $\mathrm{~N}-\mathrm{CH}_{2}-\mathrm{C}$ & $2 \mathrm{H}$ & 3.94 \\
\hline \multirow{2}{*}{$5 \mathbf{a}$} & $\mathrm{N}-\mathrm{CH}_{2}-\mathrm{O}$ & $2 \mathrm{H}$ & 4.97 \\
\hline & $\mathrm{N}-\mathrm{CH}_{2}-\mathrm{C}$ & $2 \mathrm{H}$ & 4.06 \\
\hline $6 a$ & $\mathrm{~N}-\mathrm{CH}_{2}-\mathrm{C}$ & $4 \mathrm{H}$ & 3.86 \\
\hline
\end{tabular}




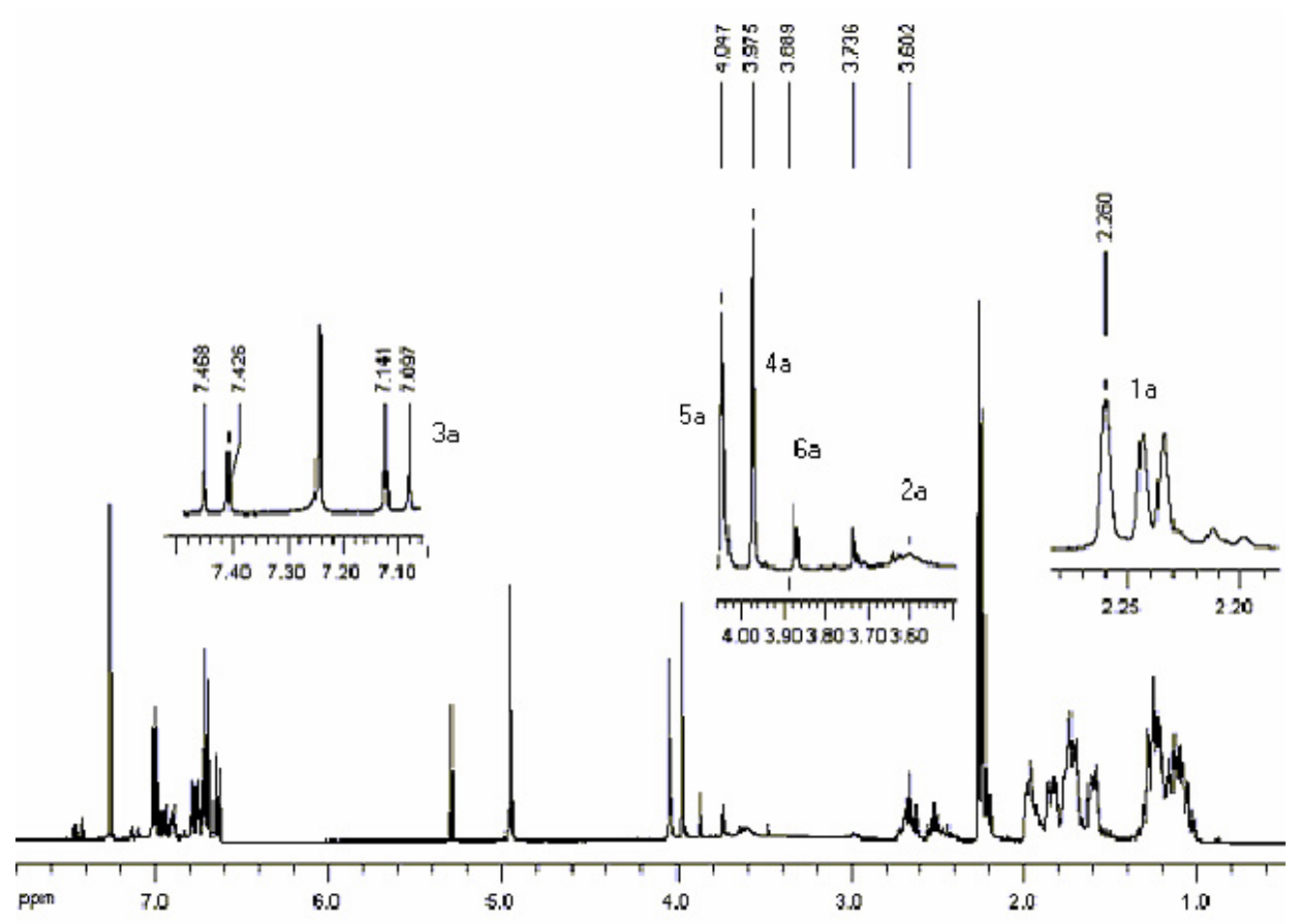

Figure 1. ${ }^{1} \mathrm{H}$ NMR spectrum of the reaction mixture.

Yields of products $\mathbf{4 a - 6 a}$ as well as conversion of $\mathbf{1 a}$ and $\mathbf{2 a}$ were evaluated basing on ${ }^{1} \mathrm{H}$ NMR spectra after 1,5 and $10 \mathrm{~h}$. After the first hour $\mathbf{2 a}$ was totally consumed, whereas the conversion of $1 \mathbf{a}$ was only about $55 \%$ and benzoxazine $\mathbf{5 a}$ was the main product (36\% yield). In subsequent hours the yield of 5a gradually decreased whereas the conversion of 1a and yields of benzylamine $\mathbf{4 a}$ and benzyldiamine $\mathbf{6 a}$ increased (Figure 2).

No significant influence of the solvent used (methanol, dioxane, chloroform and hexane) on the reaction course has been observed. Similarly, in the reaction of other phenols (1b-e) with 1,3,5-trialkyl-hexahydro-1,3,5-triazines (2b-e) in methanol or hexane, appropriate benzylamines 4b-e were isolated as the main products. The ${ }^{1} \mathrm{H}$ NMR control revealed changes analogous to that observed in the model system. 


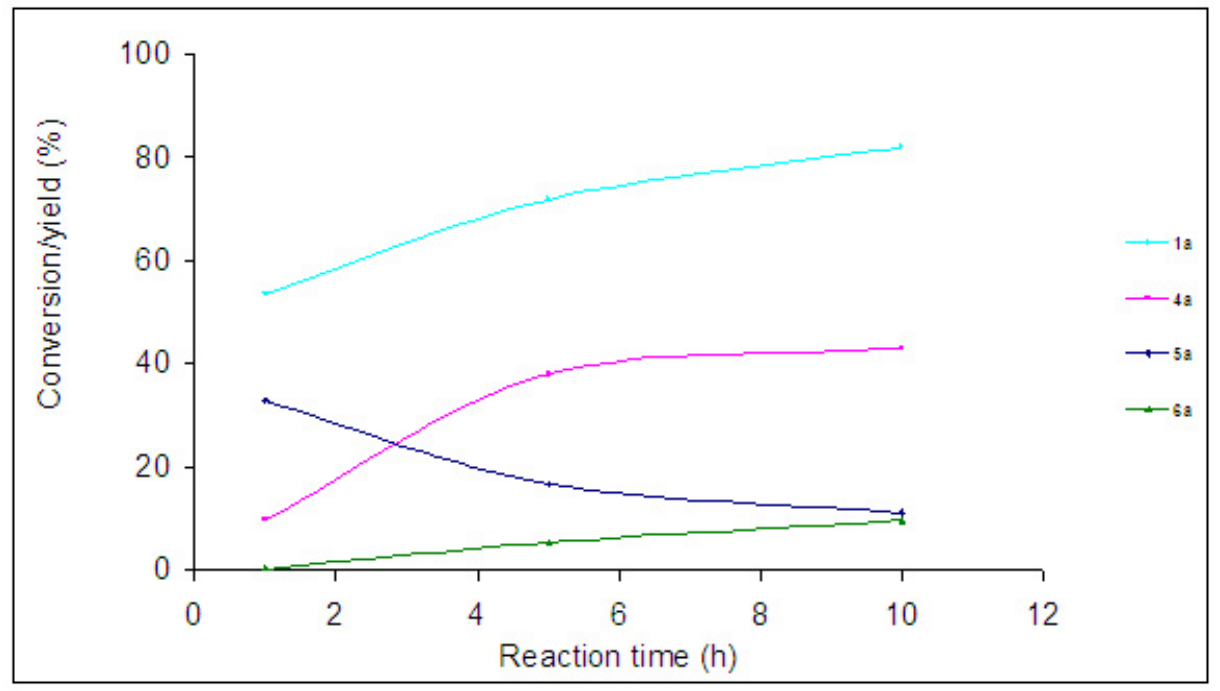

Figure 2. Conversion of 1a and yield of 4a-6a over time.

The mutual reactivity of $\mathbf{4 a}$ and $\mathbf{2 a}$ has additionally been examined. Thus, after heating of $\mathbf{4 a}$ and 2a at 3:1 ratio in refluxing methanol for $1 \mathrm{~h}, \mathbf{5 a}$ was formed with $66 \%$ yield, whereas the conversion of $4 \mathbf{a}$ was $75 \%$. 2a, 3a and traces of side products but no sign of $\mathbf{6 a}$ have been observed. No change of the reaction mixture composition after 5 and $10 \mathrm{~h}$ suggests that the reaction is reversible and reaches its equilibrium after maximum $1 \mathrm{~h}$. The presence of cyclohexylamine ( $10 \%$ of the initial amount of $\mathbf{4 a}$ ) caused the formation of a significant amount of product $\mathbf{6 a}$ ( $25 \%$ yield) in the multicomponent mixture.

Based on the results obtained, the mechanistic proposal of the investigated Mannich reaction is as follows. The first stage of the process is the addition of phenol $\mathbf{1}$ and $\mathrm{N}$ methylenealkylamine $\mathbf{3}$ with the formation of benzylamine $\mathbf{4}$, according to the aromatic electrophilic substitution mechanism (Scheme 1). Subsequently, 4 quickly reacts with the second molecule of $\mathbf{3}$ resulting in benzoxazine $\mathbf{5}$ and primary amine, therefore, the conversion of $\mathbf{1}$ is limited at this stage. The reaction of $\mathbf{4}$ with $\mathbf{3}$ is reversible, so, due to the addition of $\mathbf{3}$ with the so far unreacted 1, a further amount of $\mathbf{4}$ is being formed and $\mathbf{5}$-dominating at the beginning of the process - undergoes slow aminolysis with regeneration of 4 . This is why in the last stage of the process, while 3 is being consumed, the concentration of $\mathbf{4}$ slowly increases and that of 5 appropriately decreases. Benzyldiamine $\mathbf{6}$ results from a side reaction of $\mathbf{4}$ with $\mathbf{3}$ favoured in the presence of primary amine, which probably causes deprotonation of $\mathbf{4}$, increasing its reactivity at the same time. 


\section{Conclusions}

The reported variant of the Mannich reaction is a simple convenient and practical method of $o$ hydroxybenzylamines synthesis, ${ }^{8}$ highly competitive towards the widely used multi-step procedure: $o$-hydroxybenzaldehyde $\rightarrow o$-hydroxybenzylimine $\rightarrow o$-hydroxybenzylamine, starting from expensive or not easily obtainable aldehydes. The application of ${ }^{1} \mathrm{H}$ NMR enables analytical control of the process at every stage. The practical conclusions of the presented mechanistic proposal are as follows:

1. Reaction time reasonably influences the yields of products. If it is sufficiently short, benzoxazine $\mathbf{5}$ is the dominant product that can possibly be isolated. Only after appropriately long reaction time the maximum yield of benzylamine $\mathbf{4}$ is observed. Various isolated products of the reaction reported previously ${ }^{5,6}$ result probably from underestimation of the time factor.

2. The highest yield of $\mathbf{4}$ can be obtained by application of an equimolar or almost equimolar ratio of phenol $\mathbf{1}$ and $\mathrm{N}$-methylenealkylamine $\mathbf{3}$. The application of an excess of $\mathbf{3}$, which is traditionally expected to result in higher yield of $\mathbf{4}$ and conversion of $\mathbf{1}$, causes an increase in the yield of 5, especially after short reaction time. Even after relatively long, optimized reaction time, the excess of $\mathbf{3}$ results in lower yields of $\mathbf{4}$ and contamination of this product in the reaction mixture with $\mathbf{5}$ and $\mathbf{6}$.

\section{Experimental Section}

\section{General Procedures.}

1,3,5-Tricyclohexyl-hexahydro-1,3,5-triazine (2a). To the stirred and cooled below $50^{\circ} \mathrm{C}$ solution of $200 \mathrm{~mL}$ cyclohexylamine $(173.4 \mathrm{~g}, 1.75 \mathrm{~mol})$ in hexane $(150 \mathrm{~mL})$, formalin $(174.8 \mathrm{~g}$, $2.096 \mathrm{~mol}, 1.2$ eq.) was added over a period of $15 \mathrm{~min}$. Stirring was continued for $3 \mathrm{~h}$ at room temperature. The resulting two phases were separated. The organic phase was rinsed with water and dried over anhydrous $\mathrm{Na}_{2} \mathrm{SO}_{4}$. The solvent was evaporated to dryness under reduced pressure. The white crude product obtained $(236 \mathrm{~g})$ was crystallized from acetone $(200 \mathrm{~mL})$ resulting in white crystalline $2 \mathrm{a}(150.7 \mathrm{~g}, 78 \%)$; $\mathrm{mp} 73.3-74.2^{\circ} \mathrm{C}\left(\right.$ lit. $\left.^{9} 72.2-73^{\circ} \mathrm{C}\right)$. IR $(\mathrm{KBr})$ : 3444, 2924, $2852 \mathrm{~cm}^{-1} .{ }^{1} \mathrm{H}$ NMR $\left(400 \mathrm{MHz}, \mathrm{CDCl}_{3}\right): \delta 3.54\left(\mathrm{~s}, 6 \mathrm{H}, \mathrm{NCH}_{2} \mathrm{~N}\right), 2.40(\mathrm{tt}, J=10.7$, $3.4 \mathrm{~Hz}, 3 \mathrm{H}, \mathrm{NCH}), 1.88-0.98\left(\mathrm{~m}, 30 \mathrm{H}, \mathrm{CH}_{2}\right), 7.39$ (dd, $\left.J=17.1,0.6 \mathrm{~Hz}, 1 \mathrm{H}, \mathrm{N}=\mathrm{CH}_{2}\right), 7.04$ (dd, $\left.J=17.1,1.1 \mathrm{~Hz}, 1 \mathrm{H}, \mathrm{N}=\mathrm{CH}_{2}\right), 2.90(\mathrm{~m}, 1 \mathrm{H}, \mathrm{NCH}) .{ }^{13} \mathrm{C} \mathrm{NMR}\left(101 \mathrm{MHz}, \mathrm{CDCl}_{3}\right): \delta 68.18$, 58.31, 29.82, 26.06, 25.57, 150.43. MS (GC, $\left.\mathrm{CH}_{2} \mathrm{Cl}_{2}\right): m / z(\%): 110(100)[\mathrm{M}-\mathrm{H}]^{+}$. $\mathrm{C}_{21} \mathrm{H}_{39} \mathrm{~N}_{3}$ (333.6): Calcd. C 75.62, H 11.78, N 12.60; Found C 75.59, H 11.62, N 12.55.

Other 1,3,5-trialkyl-hexahydro-1,3,5-triazines 2c-e were obtained according to the procedure described for $\mathbf{2} \mathbf{a}$ as high-boiling oils of a characteristic smell and were used without purification. 
2-Cyclohexylaminomethyl-4-methyl-phenol (4a). 1a (4.8 g, $0.044 \mathrm{~mol}), 2 \mathrm{a}$ (6.3 g, $0.018 \mathrm{~mol})$ and methanol $(30 \mathrm{~mL})$ were refluxed for $10 \mathrm{~h}$. Samples of the mixture $(1 \mathrm{~mL})$, taken after 1,5 and $10 \mathrm{~h}$ of reaction, after removal of solvent (vacuum, room temperature), were immediately analyzed by ${ }^{1} \mathrm{H}$ NMR spectroscopy in $\mathrm{CDCl}_{3}$. The post-reaction mixture was acidified to $\mathrm{pH}$ about 1.0 with concentrated hydrochloric acid at $<10^{\circ} \mathrm{C}$. Then, water $(8 \mathrm{~g})$ was added and the mixture was concentrated to ca. $30 \mathrm{~g}$ at room temperature. After $48 \mathrm{~h}$ at $5^{\circ} \mathrm{C}$ the crystalline $4 \mathbf{a} \cdot \mathrm{HCl}$ was filtered off, washed with cold $\left(5^{\circ} \mathrm{C}\right)$ acetone $(2 \times 5 \mathrm{~mL})$ and air dried to afford $4.8 \mathrm{~g}$ $(50 \%)$ of a white solid of m.p. $221.5-222.7^{\circ} \mathrm{C}$.

To the vigorously stirred suspension of $4 \mathbf{a} \cdot \mathrm{HCl}(3 \mathrm{~g})$ in water $(20 \mathrm{~g})$ and hexane $(20 \mathrm{~g})$ aqueous ammonia was dropped in at room temperature until the $\mathrm{pH}$ of the mixture reached about 9 . The organic phase was separated, washed twice with water $(10 \mathrm{~mL})$ and dried over anhydrous $\mathrm{Na}_{2} \mathrm{SO}_{4}$. The solvent was removed under reduced pressure resulting in $2.1 \mathrm{~g}(81 \%)$ of a cream solid of pure (TLC, ethyl acetate) 4a; mp 63.9-64.6 ${ }^{\circ}$; IR (KBr): 3440, 3300, 2932, $2852 \mathrm{~cm}^{-1}$. ${ }^{1} \mathrm{H}$ NMR (400 MHz, $\mathrm{CDCl}_{3}$ ): $\delta 6.92(\mathrm{dd}, J=8.14,1.73 \mathrm{~Hz}, 1 \mathrm{H}, \mathrm{ArH}), 6.76(\mathrm{~d}, J=1.78 \mathrm{~Hz}, 1 \mathrm{H}$, $\mathrm{ArH}), 6.70(\mathrm{~d}, J=8.15 \mathrm{~Hz}, 1 \mathrm{H}, \mathrm{ArH}), 3.94\left(\mathrm{~s}, 2 \mathrm{H}, \mathrm{CH}_{2}\right), 2.50(\mathrm{tt}, J=10.18,3.76 \mathrm{~Hz}, 1 \mathrm{H}, \mathrm{NCH})$, $2.21\left(\mathrm{~s}, 3 \mathrm{H}, \mathrm{CH}_{3}\right), 1.96-1.07\left(\mathrm{~m}, 10 \mathrm{H}, \mathrm{CH}_{2}\right) \mathrm{ppm} .{ }^{13} \mathrm{C} \mathrm{NMR}\left(101 \mathrm{MHz}, \mathrm{CDCl}_{3}\right): \delta 156.00$, 128.87, 128.60, 127.81, 122.68, 116.11, 55.52, 49.59, 32.96, 25.89, 24.76, 20.39 ppm. ${ }^{13} \mathrm{C}$ NMR / DEPT $135\left(101 \mathrm{MHz}, \mathrm{CDCl}_{3}\right): \delta 128.73(+), 128.45(+), 115.97(+), 55.38(+), 49.45(-), 32.82$ $(-), 25.72(-), 24.62(-), 20.26(+)$ ppm. MS (ES, MeOH): $m / z(\%): 221(100)[\mathrm{M}+2 \mathrm{H}]^{+}, 144$ (15) $\left[\mathrm{M}+\mathrm{H}+\mathrm{Na}-\mathrm{C}_{6} \mathrm{H}_{11} \mathrm{NH}_{2}\right]^{+} . \mathrm{C}_{14} \mathrm{H}_{21} \mathrm{NO}$ (219.3): Calcd. C 76.67, H 9.65, N 6.39; Found C 76.58, H 9.62, N 6.41 .

2-Cyclohexylaminomethyl-phenol (4b), obtained analogously to $\mathbf{4 a}$; cream solid (9\% yield); mp 56.8-57. $7^{\circ} \mathrm{C}$ (lit. $\left.{ }^{10} 58-59\right)$. IR (KBr): 3268, $2928 \mathrm{~cm}^{-1} .{ }^{1} \mathrm{H}$ NMR (400 MHz, $\left.\mathrm{CDCl}_{3}\right): \delta 7.16$ $(\mathrm{m}, J=8.02,8.02,1.63 \mathrm{~Hz}, 1 \mathrm{H}, \mathrm{ArH}), 6.97(\mathrm{~m}, J=6.90 \mathrm{~Hz}, 1 \mathrm{H}, \mathrm{ArH}), 6.82(\mathrm{~m}, J=8.07,0.92$ $\mathrm{Hz}, 1 \mathrm{H}, \mathrm{ArH}), 6.76(\mathrm{~m}, J=7.39,1.12 \mathrm{~Hz}, 1 \mathrm{H}, \mathrm{ArH}), 4.02$ (s, 2H, NCH$)_{2}, 2.54$ (tt, $J=10.05,3.70$ $\mathrm{Hz}, 1 \mathrm{H}, \mathrm{NCH}), 1.98-1.08\left(\mathrm{~m}, 10 \mathrm{H}, \mathrm{CH}_{2}\right)$ ppm. ${ }^{13} \mathrm{C} \mathrm{NMR}\left(101 \mathrm{MHz}, \mathrm{CDCl}_{3}\right): \delta 158.48,128.51$, $127.98,123.07,118.81,116.39,55.57,49.68,33.02,25.87,24.77 \mathrm{ppm}$. MS $\left(\mathrm{GC} \mathrm{CH}_{2} \mathrm{Cl}_{2}\right): \mathrm{m} / z$ (\%): 205 (50) $[\mathrm{M}]^{+}, 107$ (62) $\left[\mathrm{M}+\mathrm{H}-\mathrm{C}_{6} \mathrm{H}_{11} \mathrm{NH}_{2}\right]^{+}, 77$ (34) [Ph] ${ }^{+} . \mathrm{C}_{13} \mathrm{H}_{19} \mathrm{NO}$ (205.3): Calcd. C 76.06, H 9.33, N 6.82; Found C 75.93, H 9.30, N 6.84.

In cases of $\mathbf{4 c - f}$ synthesis, hexane was used as a solvent. The products crystallized directly from post-reaction mixtures.

4-tert-Butyl-2-((tert-butylamino)methyl)phenol (4c); white solid (54\% yield); $\mathrm{mp}$ 93.193. $7^{\circ} \mathrm{C}$; IR (KBr): $32802968 \mathrm{~cm}^{-1} .{ }^{1} \mathrm{H} \mathrm{NMR}\left(400 \mathrm{MHz}, \mathrm{CDCl}_{3}\right): \delta 7.18(\mathrm{dd}, J=8.44,2.50 \mathrm{~Hz}$, 1H, ArH), 7.01 (d, $J=2.47 \mathrm{~Hz}, 1 \mathrm{H}, \mathrm{ArH}), 6.76$ (d, $J=8.44 \mathrm{~Hz}, 1 \mathrm{H}, \mathrm{ArH}), 3.94$ (s, 2H, NCH$)$, $1.29\left(\mathrm{~s}, 9 \mathrm{H}, 3 \mathrm{CH}_{3}\right), 1.22\left(\mathrm{~s}, 9 \mathrm{H}, 3 \mathrm{CH}_{3}\right) \mathrm{ppm} .{ }^{13} \mathrm{C} \mathrm{NMR}\left(100 \mathrm{MHz}, \mathrm{CDCl}_{3}\right): \delta 155.90,141.52$, $125.22,124.81,122.64,115.90,50.92,46.38,33.90,31.58,28.55$ ppm. MS (ES, MeOH): $m / z$ (\%): $236(100)[\mathrm{M}+\mathrm{H}]^{+} 163$ (19) $\left[\mathrm{M}+\mathrm{H}-\mathrm{C}_{4} \mathrm{H}_{9} \mathrm{NH}_{2}\right]^{+} . \mathrm{C}_{15} \mathrm{H}_{25} \mathrm{NO}$ (235.4): Calcd. C 76.55, H 10.71, N 5.95; Found C 76.73, H 10.55, N 6.02.

2-((Propylamino)methyl)-4-(2,4,4-trimethylpentan-2-yl)phenol (4d). White solid (40\% yield). mp 66.7-68.2 ${ }^{\circ} \mathrm{C}$. IR (KBr): $3272,2952,2872 \mathrm{~cm}^{-1}$. ${ }^{1} \mathrm{H}$ NMR (400 MHz, $\left.\mathrm{CDCl}_{3}\right): \delta 7.14(\mathrm{dd}, J=$ 
8.46, $2.36 \mathrm{~Hz}, 1 \mathrm{H}, \mathrm{ArH}), 6.95$ (d, J=2.12 Hz, 1H, ArH), 6.74 (d, J=8.45 Hz, 1H, ArH), 3.98 (s, $\left.2 \mathrm{H}, \mathrm{NCH}_{2} \mathrm{Ar}\right), 2.64\left(\mathrm{t}, J=7.07 \mathrm{~Hz}, 2 \mathrm{H}, \mathrm{NCH}_{2}\right), 1.66\left(\mathrm{~s}, 2 \mathrm{H}, \mathrm{CH}_{2}\right), 1.55\left(\mathrm{~m}, 2 \mathrm{H}, \mathrm{CH}_{2}\right), 1.32(\mathrm{~s}$, $\left.6 \mathrm{H}, 2 \mathrm{CH}_{3}\right), 0.94\left(\mathrm{t}, J=7.41 \mathrm{~Hz}, 3 \mathrm{H}, \mathrm{CH}_{3}\right), 0.71\left(\mathrm{~s}, 9 \mathrm{H}, 3 \mathrm{CH}_{3}\right) \mathrm{ppm} .{ }^{13} \mathrm{C} \mathrm{NMR}(101 \mathrm{MHz}$, $\left.\mathrm{CDCl}_{3}\right): \delta 155.65,140.36,126.16,125.88,121.58,115.43,57.06,53.07,50.50,37.77,32.32$, 31.74, 31.62, 22.69, 11.61 ppm. MS (ES, MeOH): $m / z(\%): 278(100)[\mathrm{M}+\mathrm{H}]^{+} . \mathrm{C}_{18} \mathrm{H}_{31} \mathrm{NO}$ (277.4): Calcd. C 77.92, H 11.26, N 5.05; Found C 78.36, H 11.33, N 5.10.

2-((Isopropylamino)methyl)-4-(2,4,4-trimethylpentan-2-yl)phenol (4e). White solid (64\% yield). $\mathrm{mp} 76.1-77.7^{\circ} \mathrm{C}$ (after recrystallization from hexane). IR (KBr): $3276,2964,2896 \mathrm{~cm}^{-1}$. ${ }^{1} \mathrm{H}$ NMR (400 MHz, $\mathrm{CDCl}_{3}$ ): $\delta 7.14(\mathrm{dd}, J=8.45,2.48 \mathrm{~Hz}, 1 \mathrm{H}, \mathrm{ArH}), 6.95(\mathrm{~d}, J=2.39 \mathrm{~Hz}, 1 \mathrm{H}$, ArH), 6.74 (d, $J=8.44 \mathrm{~Hz}, 1 \mathrm{H}, \mathrm{ArH}), 3.98$ (s, 2H, $\mathrm{NCH}_{2}$ ), 2.89 (sept., $J=6.56 \mathrm{~Hz}, 1 \mathrm{H}, \mathrm{NCH}$ ), $1.67\left(\mathrm{~s}, 2 \mathrm{H}, \mathrm{CH}_{2}\right), 1.32\left(\mathrm{~s}, 6 \mathrm{H}, 2 \mathrm{CH}_{3}\right), 1.15\left(\mathrm{~d}, J=6.32 \mathrm{~Hz}, 6 \mathrm{H}, 2 \mathrm{CH}_{3}\right), 0.71\left(\mathrm{~s}, 9 \mathrm{H}, 3 \mathrm{CH}_{3}\right)$ ppm. ${ }^{13} \mathrm{C}$ NMR $\left(100 \mathrm{MHz}, \mathrm{CDCl}_{3}\right): \delta 155.68,140.37,126.12,125.68,121.92,115.51,57.04$, 50.56, 48.18, 37.77, 32.31, 31.74, 31.64, 22.51 ppm. MS (ES, MeOH): $m / z(\%): 278(100)[\mathrm{M}+$ $\mathrm{H}]^{+} . \mathrm{C}_{18} \mathrm{H}_{31} \mathrm{NO}$ (277.4): Calcd. C 77.92, H 11.26, N 5.05; Found C 77.69, H 10.99, N 5.12.

3-Cyclohexyl-6-methyl-3,4-dihydro-2H-1,3-benzoxazine (5a). To the solution of 4 a (15 $\mathrm{g}$, $0.068 \mathrm{~mol})$ in ethanol $(100 \mathrm{~mL})$ while stirring, formalin $(6.2 \mathrm{~g}, 0.0816 \mathrm{~mol})$ was dropped-in at room temperature. After $1 \mathrm{~h}$ of refluxing the total conversion of $\mathbf{4 a}$ was observed (TLC, ethyl acetate). The oily product obtained after removal of the solvent (vacuum, room temperature) dissolved in $\mathrm{CDCl}_{3}(100 \mathrm{~mL})$ was purified with silica gel (10 g Merck, 0.040-0.063 mm) resulting in $17 \mathrm{~g}$ of a slightly yellow oil of 5 (98\%). An analytical sample was crystallized from $\mathrm{CH}_{2} \mathrm{Cl}_{2}$. Colorless solid; mp 38.3-39.0 ${ }^{\circ} \mathrm{C}$. IR (film/KBr): 3464 2932, $2856 \mathrm{~cm}^{-1}$. ${ }^{1} \mathrm{H}$ NMR (400 $\left.\mathrm{MHz}, \mathrm{CDCl}_{3}\right): \delta 6.91(\mathrm{ddd}, J=8.25,1.50,0.66 \mathrm{~Hz}, 1 \mathrm{H}, \mathrm{ArH}), 6.78(\mathrm{~d}, J=1.32 \mathrm{~Hz}, 1 \mathrm{H}, \operatorname{ArH})$, $6.67(\mathrm{~d}, J=8.25 \mathrm{~Hz}, 1 \mathrm{H}, \mathrm{ArH}), 4.97\left(\mathrm{~s}, 2 \mathrm{H}, \mathrm{OCH}_{2} \mathrm{~N}\right), 4.06\left(\mathrm{~s}, 2 \mathrm{H}, \mathrm{NCH}_{2}\right), 2.71(\mathrm{~m}, 1 \mathrm{H}, \mathrm{NCH})$, $2.26\left(\mathrm{~s}, 3 \mathrm{H}, \mathrm{CH}_{3}\right), 2.02-1.20\left(\mathrm{~m}, 10 \mathrm{H}, \mathrm{CH}_{2}\right) \mathrm{ppm} .{ }^{13} \mathrm{C} \mathrm{NMR}\left(101 \mathrm{MHz}, \mathrm{CDCl}_{3}\right): \delta 152.75$, $129.32,127.87,127.24,121.27,116.13,80.10,58.57,47.25,31.54,25.82,25.42,20.55 \mathrm{ppm}$. MS (ES, MeOH): $m / z(\%): 232(57)[\mathrm{M}+\mathrm{H}]^{+}, 121(100)\left[\mathrm{M}+\mathrm{H}-\mathrm{C}_{6} \mathrm{H}_{11} \mathrm{NHCH}_{3}\right]^{+} . \mathrm{C}_{15} \mathrm{H}_{21} \mathrm{NO}$ (231.3): Calcd. C 77.88, H 9.15, N 6.05; Found C 77.90, H 9.13, N 6.06.

2,6-Bis((cyclohexylamino)methyl)-4-methylphenol (6a). A solution of 4a (7.5 g, $0.034 \mathrm{~mol})$, cyclohexylamine $(3.4 \mathrm{~g}, 3.8 \mathrm{~mL} 0.034 \mathrm{~mol})$ and formalin $(2.6 \mathrm{~g}, 0.034 \mathrm{~mol})$ in ethanol $(50 \mathrm{~mL})$ was refluxed for $35 \mathrm{~h}$. In the final mixture $4 \mathbf{a}$ (10\% of the initial amount), 5a (7.1\% yield) and $\mathbf{6 a}$ (43\% yield) were detected. It was acidified ( $\mathrm{pH}$ ca. 1) with hydrochloric acid (36\%) and concentrated to about half of the volume under reduced pressure. A white solid of $\mathbf{6 a} \cdot \mathrm{HCl}$ (separated after 10 days at $-10^{\circ} \mathrm{C}$ ) was transformed into $6 \mathbf{a}$ according to the procedure described for $\mathbf{4 a}$ resulting in $\mathbf{6 a}$ as a yellow oil (0.6 g, 5.3\% total yield). IR (film/KBr): 3304, 2928, 2852 $\mathrm{cm}^{-1} .{ }^{1} \mathrm{H}$ NMR (400 MHz, $\left.\mathrm{CDCl}_{3}\right): \delta 6.81(\mathrm{~s}, 2 \mathrm{H}, 2 \mathrm{ArH}), 3.86\left(\mathrm{~s}, 4 \mathrm{H}, 2 \mathrm{NCH}_{2}\right), 2.49(\mathrm{tt}, J=$ $10.25,3.76 \mathrm{~Hz}, 2 \mathrm{H}, 2 \mathrm{NCH}), 2.21\left(\mathrm{~s}, 3 \mathrm{H}, \mathrm{CH}_{3}\right), 1.96-1.11\left(\mathrm{~m}, 20 \mathrm{H}, \mathrm{CH}_{2}\right) \mathrm{ppm} .{ }^{13} \mathrm{C} \mathrm{NMR}(101$ $\left.\mathrm{MHz}, \mathrm{CDCl}_{3}\right): \delta 154.21,128.32,127.46,124.74,55.92,48.02,33.22,26.05,24.92,20.45 \mathrm{ppm}$. MS (ES, MeOH): $m / z(\%): 331$ (100) $[\mathrm{M}+\mathrm{H}]^{+} . \mathrm{C}_{21} \mathrm{H}_{34} \mathrm{~N}_{2} \mathrm{O}$ (330.4): Calcd. C 76.31, H 10.37, N 8.48; Found C 76.20, H 10.35, N 8.47. 
Reaction of 4a with 2a. A solution of $4 \mathbf{a}(2 \mathrm{~g}, 0.009 \mathrm{~mol}), 2 \mathrm{a}(1 \mathrm{~g}, 0.003 \mathrm{~mol})$ in methanol $(20 \mathrm{~mL})$ was refluxed for $10 \mathrm{~h}$. The reaction was monitored by ${ }^{1} \mathrm{H}$ NMR as described for the synthesis of $\mathbf{4 a}$. The conversion of $\mathbf{4 a}$ was $75 \%$ and yield of $\mathbf{5 a}-66 \%$. No traces of $\mathbf{6 a}$ were detected. In another run of the reaction, $10 \%(0.9 \mathrm{mmol})$ of cyclohexylamine was additionally introduced. After $10 \mathrm{~h}$ of refluxing the conversion of $\mathbf{4 a}$ was $75 \%$, yields of products: $\mathbf{5 a}$ (25\%), 6a $(28 \%)$.

\section{Supplementary Information Available}

Copies of 1H NMR and 13C NMR spectra of 4a-e, 5a and $\mathbf{6 a}$

\section{Acknowledgements}

This work was financially supported by Warsaw University of Technology (504/G/1021/0441/000). The authors kindly thank Prof. Kazimierz B. Starowieyski for valuable discussions, Dr. Thomas Zevaco for MS spectra and DEPT 135 analysis of 4a and Ms. Renata Przedpełska for assistance in the preparation of this paper.

\section{References and Notes}

1. (a) Bujnowski, K.; Adamczyk, A.; Synoradzki, L. Org. Prep. Proced. Int. 2007, 39, 153 and references cited therein. (b) Bujnowski, K.; Adamczyk, A.; Synoradzki, L. Org. Prep. Proced. Int. 2007, 39, 417.

2. (a) Tramontini, M.; Angiolini, L. Tetrahedron 1990, 46, 1791. (b) Velázquez A. Ma.; Torres L. A.; Díaz G.; Ramírez A.; Hernández R.; Santillán H.; Martínez L.; Martínez I.; DíazBarriga S.; Abrego V.; Balboa M. A.; Camacho B.; López-Castañares R.; Dueñas-González A.; Cabrera G.; Angeles E. ARKIVOC 2006, (ii), 150.

3. Mlostoń, G.; Gendek, T. Helv. Chim. Acta 1998, 81, 1585.

4. Giumanini, G.; Verardo, G.; Cauci, S. J. Prakt. Chem. 1987, 329, 417.

5. Möhrle, H.; Tröster, K. Arch. Pharm. 1982, 315, 619.

6. Kostyuchenko, V. M.; Kiryukhina, G. A. Zh. Org. Khim. 1985, 21, 2243.

7. Exner, L. J.; Craig, W. E. U.S. Patent 2 750.416, 1956; Chem. Abstr. 1957, 51, 2034 b.

8. Bujnowski, K.; Adamczyk-Woźniak, A.; Synoradzki, L. PL Patent Appl. P32823, 2007.

9. Taguchi, M.; Aikawa, N.; Tsukamoto, G. B. Chem. Soc. Jpn. 1988, 61, 24316.

10. Burke, W. J.; Stephens, C. W. J. Am. Chem. Soc. 1952, 74, 1518. 